\title{
The Art of Dying Well according to Erasmus of Rotterdam and Teresa of Ávila
}

\author{
Dominika Sieruta
}

Boston College School of Theology and Ministry (Brighton, MA)

\begin{abstract}
Contemporary conversations about death and dying are lost and unsatisfying on many levels. This phenomenon subsists not only in fields like bioethics, but also in religion and spirituality. Modern culture is preoccupied with seeking ways to live a longer, youthful life, ignoring the inevitable forthcoming of death. One period during which the topic of death and dying was reflected upon by the common Christian was between the fifteenth and the seventeenth centuries, during which a specific genre of literature was formed: ars moriendi. This genre attempted to provide intellectual, cultural and religious answers as to how death should be understood and ritualized. Two spiritual writers who contributed to the understanding of ars moriendi are Desiderius Erasmus and Teresa of Ávila. What unites these figures of the Catholic tradition is their attempt to show that preparation for death is a lifelong process of cultivating appropriate virtues.
\end{abstract}

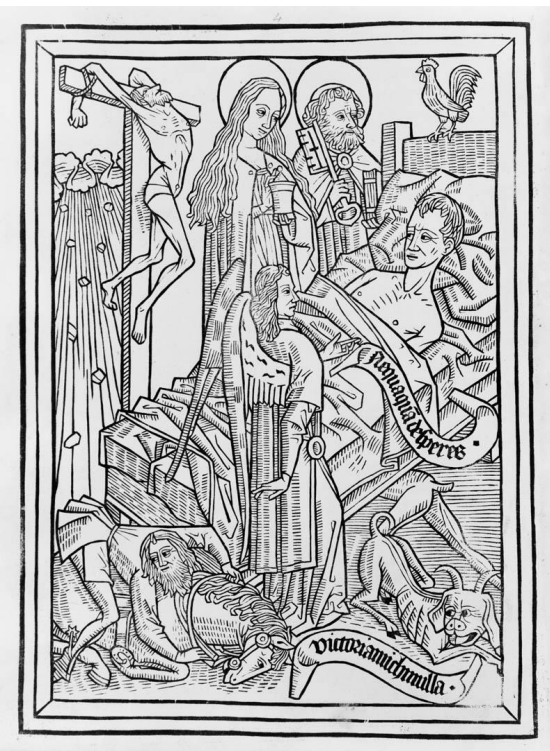

A page from the Ars Moriendi, unknown artist, Germany (ca. 1466).
Text

"Jesus said to her, 'I am the resurrection and the life. Those who believe in me, even though they die, will live, and everyone who lives and believes in me will never die. Do you believe this?"” (John 11:25-26 NRSV). Whenever we hear these words of Jesus proclaimed, they present a sense of hope and wonder in what Christ is for us: the life and resurrection. Christ, the Christus Victor, defeated death - this is one of the major grounding principles of 


\section{SIERUTA: THE ART OF DYING WELL}

faith known to all Christians. Yet, when we are given the opportunity to reflect on our own mortality, we can be swathed with fear, denial, and doubts. There is a gap between the glorious expectation of life everlasting preached in the Gospels and our approach to our own death in this life.

Many would agree that contemporary conversations about death and dying are lost and unsatisfying on many levels. ${ }^{1}$ Modern culture is much more preoccupied with seeking ways to live a longer, youthful life, willfully ignoring and hiding from the inevitable forthcoming of death, a word that today has many soothing euphemisms. But to say that conversations about death are lost and unsatisfying implies that at some point in time people had adequate solutions to coming to terms with mortality. ${ }^{2}$ The fifteenth to seventeenth centuries was a period during which the common Christian sought to understand the topic of death and dying. A specific genre of literature, ars moriendi, or, the art or craft of dying, developed and attempted to provide intellectual, cultural, and religious answers as to how death and dying should be understood and ritualized.

The legendary phrases memento mori, "remember that you will die," and carpe diem, "seize the day," were medieval concepts that encouraged all people to reflect on mortality and live today as if it were one's last day. Two spiritual writers who contributed to the development of ars moriendi are Desiderius Erasmus of Rotterdam and Teresa of Ávila. What unites these figures of the Catholic tradition is their attempt to show that dying well, also understood as preparation for death, is a lifelong process of cultivating appropriate virtues. The art of dying (ars moriendi) is really the art of living (ars vivendi); in other words, how we live is how we prepare for death. The historical retrieval of Erasmus and Teresa can shed light on how we understand death and dying today, which, according to them, was entirely dependent on moral ethics of life.

\footnotetext{
${ }^{1}$ Christopher P. Vogt, Patience, Compassion, Hope, and the Christian Art of Dying Well (Lanham, MD: Rowman \& Littlefield Publishers, 2004), 15.

${ }^{2}$ Vogt, 15.
} 


\section{SIERUTA: THE ART OF DYING WELL}

Desiderius Erasmus of Rotterdam (1466-1536), a Dutch Catholic priest, humanist and scholar of the northern Renaissance period, is deeply linked with the ars moriendi tradition. He believed that "preparation for death must be practiced through our whole life."3 His work, "Preparing for Death," focuses on essential aspects of Christian faith needed for a "good" death. This fundamentally pastoral work illuminates the pervasive human fear about the haunting reality of death and claims that the remedy for this anxiety is Christ. This work is directed to all people, Christians and non-Christians alike, who live in terror of death, which according to Erasmus, arises from not knowing God or not knowing of God's mercy. ${ }^{4}$

Teresa de Jesús (1515-1582), a Doctor of the Catholic Church, is one of the most esteemed female saints of all time. The awe-inspiring life of this great mystic may be seen in exemplary form in her book, The Way of Perfection, which seeks to draw the individual reader into a deeper relationship with Christ through prayer and virtuous living. ${ }^{5}$ The Way of Perfection cannot be read without noticing Teresa's heavy emphasis on the importance of virtues. ${ }^{6}$ Written for the twelve sisters from the Convent of St. Joseph in Ávila, this book serves primarily as a spiritual and practical handbook that teaches how sisters living cloistered life daily should strive for perfection, or what Teresa also calls "holy freedom."7 Detachment and humility are the two most sought-after virtues in this work.

\footnotetext{
${ }^{3}$ Desiderius Erasmus, "Preparing for Death (De preparatione ad mortem)," trans. John N. Grant, ed. John W. O'Malley, in Spiritualia and Pastoralia, Vol. 70 of The Collected Works of Erasmus (Toronto: University of Toronto Press, 1998), 398.

${ }^{4}$ Vogt, Christian Art of Dying Well, 18.

${ }^{5}$ Although Teresa's works are not explicit contributions to the ars moriendi tradition per se, death was always a central topic to Teresa's spirituality. The Way of Perfection was written in 1577 only a few decades after Erasmus' Preparing for Death. In other words, Teresa wrote at a time when the ars moriendi tradition was already incorporated into the cultural context of sixteenth century Spain.

${ }^{6}$ Even though Teresa discusses prayer and contemplation in her other major works, I focus on The Way of Perfection because of its emphasis on Christian perfection in virtue throughout one's entire life.

${ }^{7}$ Teresa of Ávila, The Way of Perfection, in Vol. 2 of The Collected Works of St. Teresa of Avila, trans. Kieran Kavanaugh and Otilio Rodriguez, (Washington, DC: ICS Publications, 1987), §10.1.
} 


\section{SIERUTA: THE ART OF DYING WELL}

Erasmus and Teresa both emphasize habitual prayer and contemplation in understanding the phenomenon of death. Erasmus introduces the importance of contemplation with a Pauline reference to "transient" and "intransient" things, where the only intransient being is God and that which pertains to the heavenly kingdom. ${ }^{8}$ Everything else - that which pertains to the world and is seen-is transient. He describes this transience in the following reflection:

We pass through infancy without awareness of what is happening, our youth flies past as we are engaged in many different activities, our maturity is taken up with worries of all kinds, old age creeps upon us unawares. What is the sum of all this but a moment of time compared with the eternity to which we willingly go if we have lived an upright life here, to which we are dragged if we have lived a wicked one? Serious contemplation of these things is no worthless remedy against our horror of death. ${ }^{9}$

Reflection on the transience of life leads the way to meditation on that which is eternal. Erasmus is devoted to showing that all of life is a "movement of time" lived either uprightly or wickedly. However, one's entire lifespan, from infancy to old age, is time that can be invested in not only coming to peace with our own death, but also knowing God more. He deems such meditationson the transience of the world as well as the unchanging nature of God-as remedy for the instilled fear people have of dying.

Although Teresa's book is not a manual for coping with death in itself, themes of eternal life and death most certainly emerge from the grand scheme of her writings. Like Erasmus, she provides scenarios of possible reflections, mainly on matters of detachment. The fruit of this virtue is inner "holy freedom," such as freedom from bodily comfort, honor, and wealth. ${ }^{10}$ However, freedom also relates to Teresa's understanding of heaven and union with God, which contrasts with her visions of a suffocating hell. In Teresa's understanding, the virtue of detachment may also

\footnotetext{
${ }^{8}$ Erasmus, "Preparing for Death," 396.

${ }^{9}$ Erasmus, 407.

${ }^{10}$ See Teresa of Ávila, The Way of Perfection, $\$ 19.7$.
} 


\section{SIERUTA: THE ART OF DYING WELL}

be acquired through contemplation. She provides the following explanation: "A great aid to going against your will is to bear in mind continually how all is vanity and how quickly everything comes to an end. This helps to remove our attachment to trivia and center it on what will never end."11 Interestingly, Teresa recognizes that people may deem contemplation weak, which in our modern understanding translates as ineffective, useless, and outdated. Even in many faith-based ministry settings, contemplation and prayer are difficult to implement, let alone cultivate. However, from experience, Teresa assures us that if carried out well, the benefit will definitely be known to the soul.

Contemplation of transience and the practice of virtue are applicable to Christians and nonChristians alike. Still, it is Christ that Teresa and Erasmus view as the perfect model to contemplate. ${ }^{12}$ Erasmus displays a fondness towards the three theological virtues - faith, hope, and charity-believing that they are indispensable for overcoming the fear of death. ${ }^{13}$ Having faith in Christ and hope in his promise brings consolation, and, therefore, diminishes one's fear of death. Erasmus supplements this core message with "soldier of Christ" imagery, noting that the soldier of Christ regards the body not as a permanent home, but a tent pilgrimaging to the true home in heaven. ${ }^{14}$ In viewing the body as a tent in which we make the journey of living a morally good life, death becomes a "gateway to heaven." 15 In this sense, death, which was previously a horrifying end, is now "the entrance to heavenly joys." 16

Another remedy for the fear of death proposed by Erasmus is the communion of saints in the Body of Christ, the church. He strongly believes that all faithful Christians should keep in mind

\footnotetext{
11 Teresa of Ávila, The Way of Perfection, \$10.2.

12 Vogt, Patience, Christian Art of Dying Well, 18.

13 Vogt, Patience, 19.

${ }^{14}$ Erasmus, Preparing for Death, 423.

15 Erasmus, 407.

${ }^{16}$ Erasmus, 407.
} 


\section{SIERUTA: THE ART OF DYING WELL}

that they belong to a body that transcends the temporal realm and includes all those who are already in the kingdom of God, namely, the saints. If I am aware that the body of the church is interceding for my soul, then that may help console me. Erasmus desires to show that no one is abandoned if helped by "thousands of saints." 17 We transition from the physical realm of life in community, into another, the communion of saints. Just as one should never remove the eyes of faith from Christ, so should one contemplate "universal fellowship" in the "communion of the whole church."18

For Teresa of Ávila, death was not only a topic of daily reflection, but also a constant reality. Carlos Erie, in his book From Madrid to Purgatory, comments that "Teresa often spoke of self-renunciation as a form of death, as an emptying of the human will and dying to the sensual world." 19 Teresa's persistent detachment from earthly possessions is in part training for the moment of her death. On the one hand, a person will either resign from life willingly, or, on the other, be forced to give it up. The last four verses of one of Teresa's most well-known poems, "Vivo sin vivir en mi," perfectly illustrate her readiness to be with God and her joy in dying:

Only with that surety

I will die do I live,

Because in dying,

My hope in living is assured.

Death, bringing life,

Do not tarry; I await you,

I die because I do not die.

See how love is strong.

Life, do not trouble me.

See how all that remains

Is in losing you to gain.

Come now, sweet death,

Come, dying, swiftly.

\footnotetext{
${ }^{17}$ Erasmus, 422.

18 Erasmus, 436.

${ }^{19}$ Carlos M. N. Eire, From Madrid to Purgatory: The Art and Craft of Dying in Sixteenth-Century Spain (Cambridge: Cambridge University Press, 1995), 394.
} 


\section{I die because I do not die.}

That life from above,

That is true life, Until this life dies, Life is not enjoyed. Death, be not aloof; In dying first, may life be, I die because I do not die.

Life, what can I give To my God living in me, If not to lose you, Thus to merit Him? In dying I want to reach Him alone whom I seek:

I die because I do not die. ${ }^{20}$

This poem echoes St. Paul's words in the First Letter to the Corinthians: "I die everyday! That is as certain, brothers and sisters, as my boasting of you-a boast that I make in Christ Jesus our Lord" (1 Cor. 15:31 NRSV). Paul and Teresa both have a strong sense of power over death. In her poem, Teresa exudes familiarity, closeness, and authority over death as she speaks to it directly: "Death, do not tarry!" Teresa is not horrified by the thought of death, nor is death controlling her actions. For the Spanish mystic, death is truly and simply the "gateway to heaven" that Erasmus says it should be. Teresa's profound play on words, "I die because I do not die," provokes an image of the dying of the self so that Christ may increase instead (John 3:30). The more Christ-like one becomes, the easier the transition from earthly to eternal life is. Her holistic perspective on the art of dying through the art of living is a commendable example for us all.

${ }^{20}$ Teresa of Avila, "Vivo sin vivir en mi" in The Collected Works of St. Teresa of Avila, Vol. 3, trans. Kieran Kavanaugh and Otilio Rodriguez (Washington, DC: Institute of Carmelite Studies, 1985), 419. Emphasis in original. 


\section{SIERUTA: THE ART OF DYING WELL}

Erasmus and Teresa both view contemplation on one's life and on the humanity of Christ as an important step towards cultivating an appropriate set of virtues, such as faith, hope and charity, as well as humility and detachment. Both figures would agree that a good preparation for death is a twofold process: contemplation (e.g., on life, the communion of saints, and the life of Jesus), which paves way to knowledge: self-knowledge, knowledge of God and perfection in virtue.

One of my favorite songs of all time is a 2002 Polish alternative tune entitled "I Would Like to Die Out of Love" [Chciałbym Umrzeć z Miłości] by Myslovitz. It is seven minutes long, its length adding to its very contemplative aura. What attracts me to it is the peace and joy I experience when listening to it, even though the main theme is death, and the way it makes me ponder my own existence. Notice that the title begins with the words, "I would like to." Even though we naturally do not have a choice as to the circumstances of our death, we can still cultivate "holy freedom" (in Teresa's words) to steer the course of our dying as we are guided by a meaning of death, all chosen and determined by no other than ourselves.

We need to foster communities where virtue through prayer, contemplation, and practice is cultivated and encouraged. This should be considered in all kinds of settings: educational, artistic, work settings, and, above all, in religious settings. When we preach that Jesus is the life and resurrection and gives us life everlasting, we should remember the journey that needs to be taken to arrive there. When we understand that a life well lived implies dying well first, only then we can step into eternity. That being said, we need not fear talking about death. We should not fear witnessing death around us, even though death and dying may be so hidden from our eyes today. Teresa and Erasmus not only provide clues as to how people can face death with comfort, but also how contemplation on death can make them better individuals here and now. Let us learn from the 


\section{SIERUTA: THE ART OF DYING WELL}

ars moriendi tradition and these great thinkers so that death and dying may become friend and companion on the journey to life everlasting. 


\section{SIERUTA: THE ART OF DYING WELL}

\section{Bibliography}

The New Oxford Annotated Bible: New Revised Standard Version: With the Apocrypha. Edited by Michael David Coogan, et al. New York: Oxford University Press, 2010.

Eire, Carlos M. N. From Madrid to Purgatory: The Art and Craft of Dying in Sixteenth-Century Spain. Cambridge: Cambridge University Press, 1995.

Erasmus, Desiderus. "Preparing for Death (De preparatione ad mortem)." In Spiritualia and Pastoralia, translated by John N. Grant, edited by John W. O'Malley, vol. 70 of The Collected Works of Erasmus, 389-450. Toronto: University of Toronto Press, 1998.

Pabel, Hilmar M. "Humanism and Early Modern Catholicism: Erasmus of Rotterdam's Ars Moriendi." In Early Modern Catholicism: Essays in Honour of John W. O'Malley, S.J., edited by Kathleen M. Comerford and Hilmar M. Pabel, 26-45. Toronto: University of Toronto Press, 2001.

Teresa of Avila. The Collected Works of St. Teresa of Avila. 3 vols. Translated by Kieran Kavanaugh, O.C.D. and Otilio Rodriguez, O.C.D. Washington, DC: ICS Publications (Institute of Carmelite Studies), 1976-85.

Vogt, Christopher P. Patience, Compassion, Hope, and the Christian Art of Dying Well. Lanham, MD: Rowman \& Littlefield Publishers, 2004. 